This is a pre-copyedited, author-produced version of an article accepted for publication in Social Forces following peer review. The version of record Christopher Kollmeyer, John Peters; Financialization and the Decline of Organized Labor: A Study of 18 Advanced Capitalist Countries, 1970-2012, Social Forces, is available online at: https://doi.org/10.1093/sf/soy105

\title{
Financialization and the Decline of Organized Labor: A Study of 18 Advanced Capitalist Countries, 1970 to 2012
}

by

Christopher Kollmeyer

University of Aberdeen

John Peters

Laurentian University

Direct correspondence to Christopher Kollmeyer, Department of Sociology, University of Aberdeen, AB24 3FX, Scotland, United Kingdom; email: c.kollmeyer@abdn.ac.uk; or John Peters, School of Northern and Community Studies, Laurentian University, Sudbury Ontario, Canada, P3E 2C6; email: jpeters@laurentian.ca. 


\title{
Financialization and the Decline of Organized Labor: A Study of 18 Advanced Capitalist Countries, 1970 to 2012
}

\begin{abstract}
Is financialization contributing to the slow decline of union density that is occurring across most advanced capitalist countries? Combining insights from literatures on financialization, corporate governance, and comparative political economy, we argue that the growing dominance of finance within advanced capitalism weakens trade unions through several channels, and plays an important but underappreciated role in the deunionization of national workforces. Using data from 18 advanced capitalist countries over several decades, this assertion is tested against the literature's existing explanations for declining union density. Results from panel regression models suggest that financialization is an important cause of union decline, but that its particular effects vary between different types of advanced capitalism. The study concludes by arguing that financialization creates new interconnections between firms and finance capital, resulting in business practices that ultimately put downward pressure on union densities across advanced capitalist countries.
\end{abstract}




\section{Financialization and the Decline of Organized Labor: A Study of 18 Advanced Capitalist Countries, 1970 to 2012}

\section{INTRODUCTION}

This study examines financialization's role in the continuing erosion of union density occurring in most advanced capitalist countries over recent decades. Because the implications of union decline are far-reaching and profound, a large literature examines the causes of this phenomenon. Extant explanations center on the decentralization of collective bargaining and the waning success of left-labor parties (Baccaro and Howell 2011, 2017; Brady 2007; Western 1995, 1997). Other explanations emphasize the decline of industrial employment (Kollmeyer 2018; Lee 2005), the weakening of class solidarity due to immigration (Lee 2005), and the shrinking of the public-sector economy (Scruggs and Lange 2002). Similarly, certain labor market institutions, such as the Ghent system, clearly help unions attract and sustain members (Brady 2007; Sano and Williamson 2008; Scruggs and Lange 2002; Western 1997). But debates persist over whether globalization and the concomitant surge in trade expose organized labor to outsourcing and debilitating wage competition, or whether resulting economic growth and new employment opportunities counter these forces (cf. Brady 2007; Scruggs and Lange 2002; O'Farrell 2010).

Building on literatures that address financialization and corporate governance, we seek to move debates on union decline in a new direction. In general, we contend that the growing dominance of finance weakens and liberalizes core labor market institutions such as unions. This occurs because financialization forges new links between firms and their financial stakeholders, ultimately leading to management strategies that emphasize the reduction of labor costs and the distribution of costsavings back to financial stakeholders. This represents a significant change from the post-war business models, in which firms sought a more judicious balance between the pecuniary interests of capital and labor. Additionally, finance is becoming more central to the operations of non-financial corporations, driving a process of "rent-seeking" whereby firms and financial institutions improve their economic positions by shifting income and resources away from workers and other stakeholders (Durand 2017; Lapavitsas 2014; Roberts and Kwon 2017; Tomaskovic-Devey and Lin 2011). In the present study, we extend these ideas, arguing that financialization also drives a longterm process of labor-market and corporate restructuring, which in turn fundamentally 
weakens union power and reduces union membership. In this way, we link the rise of finance-fuelled capitalism to the ongoing deunionization of national workforces.

Despite the clear plausibility that financialization lowers union density, studies that systematically assess this possibility are limited (Darcillon 2015; Meyer Forthcoming). We note that some comparative studies consider financial openness within the context of globalization (Lee 2005; Scruggs and Lange 2002; Vachon, Wallace, and Hyde 2016), and that some case studies consider financialization's impact on organized labor within individual countries (Batt and Appelbaum 2014; Gospel, Pendleton, and Vitols 2013). Yet comprehensive panel studies exploring financialization and its effect on union density are lacking. To fill this gap in the literature, we use panel data from 18 advanced capitalist countries over recent decades to test our financialization hypothesis against the literature's primary explanations for union decline. We measure financialization across four domains-capital market intensity, inward portfolio flows, financial sector size, and corporate indebtedness-and consider potential moderating factors linked to differences between liberal and coordinated forms of advanced capitalism. We also consider the possibility of endogeneity bias arising from reverse causation. Our regression results show that financialization is negatively linked to union density across our sample, but that the specific dynamics vary between liberal and coordinated forms of capitalism. We conclude by arguing that financialization plays an important role in the deunionization of national workforces and constitutes another major factor in the shifting balance of power between capital and labor.

\section{FinANCIALIZATION AND UNION DECLINE}

The following section outlines four causal mechanisms linking financialization to union decline. We pay particular attention to how specific aspects of financialization affect firm ownership, control, and business operations. Building on critical literatures, we argue that financialization fundamentally transforms the relationship between financial markets and non-financial corporations (Durand 2017; Duménil and Lévy 2011; Forhoohar 2016; Krippner 2011; Lapavitsas 2014), and that through a number of overlapping and reinforcing channels, finance reshapes labor relations and economic activities in ways that reduce unionized employment. These general effects, however, are partially shaped and deflected by institutional differences characterizing different forms of advanced capitalism. Our general expectation is that financialization puts 
downward pressure on unionization across advanced capitalism, but that the specific ways in which this occurs vary between liberal and coordinated forms of capitalism.

\section{Capital Markets and the "Shareholder Model" of Business}

The growing scope of capital markets and the associated rise of the "shareholder model" of corporate governance represent a first key link between financialization and union decline (Cobb 2016; Gospel and Pendleton 2005; Fligstein 2001; Jacoby 2008; Lazonick 2011b). In contrast to frameworks that emphasize distinct "varieties of capitalism" and differences between "patient" and "market-based" financing, recent literature emphasizes more universal ways that investors can exert pressure on firms to reshape corporate governance and business operations (Batt and Appelbaum 2014; Lapavitsas 2014; Durand 2017). Previously, corporations were typically held by wealthy families and dispersed shareholders operating at the national level. Now, corporations are mainly held by financial firms and institutional investors, such as mutual funds, pension funds, exchange-traded funds, and investment management corporations (Fichtner, Heemskerk, and Garcia-Bernardo 2017; Huizinga and Jonung 2005; Lazonick and O'Sullivan 2000). For instance, institutional investors now own approximately 75 percent of the largest publicly traded corporations in the United States, more than 54 percent of those in Western Europe (Celik and Isaksson 2014; Observatoire de l'Epargne Europeene and Services 2013), and more than 80 percent in Europe's largest economy-Germany (Deutsche Bundesbank 2014).

Change in firm ownership brought about by financialization may not necessarily change actual corporate governance, but it can result in the overhaul of corporate operations and the liberalization of employment relations (Crotty 2005; Davis 2016; Durand 2017; Forhoohar 2016). In contrast to standard business practices of the midtwentieth century, today's financialized firms characteristically operate under a "shareholder model" of corporate governance, in which firms focus more narrowly on returns to investors and often use their resources to purchase financial assets rather than to invest in normal business operations (Batt and Appelbaum 2013; Fligstein 2001; Lapavitsas 2014; Lazonick 2011a; Lazonick and O’Sullivan 2000). Furthermore, affected firms use shorter time frames to evaluate business investment decisions, making them more likely to undertake corporate restructuring and shed workers in the effort to lower costs, boost profits, and increase share prices (Crotty 2005; Davis 2009; Lin 2016; Orhangazi 2008). But, in general, finance derives its profits from rents taken from 
productive activities and this often entails shifting corporate operations toward financial channels and away from physical investment and payrolls (Durand 2017; Lin and Tomaskovic-Devey 2013).

Importantly, this business model is linked with the emergence of aggressive human relations strategies (Cushen and Thompson 2016; Lazonick and O'Sullivan 2000; Thompson 2013). Here the general argument is that finance capital increasingly compels non-financial firms to adopt human resource strategies that emphasize labor costs reduction as a means of bolstering income available for shareholders. The implementation of this strategy, some scholars contend, drove waves of corporate downsizing and outsourcing (Fligstein 2001; Fligstein and Shin 2007; Jung 2014; Lazonick and O'Sullivan 2000; Lin 2016) and heightened the use of part-time and temporary employees (Murphy and Turner 2014; Slaughter 2007). It also prompted firms to push for employer-friendly forms of collective bargaining and watered-down employment protections (Cobb 2016; Darcillon 2015), and sometimes reduced unionized employment in particular (Fligstein and Shin 2007). However, as Jackson, Höpner, and Kurdelbusch (2006) and Barker (2010) argue, the introduction of a shareholder model in Germany - a country with extensive corporate and unionized workforce coordination - has not been wholly negative. Here profit-sharing between shareholders and unionized labor purportedly increases the attractiveness of unionization for some workers, although this may precipitate rising income inequality and falling wage shares (Detzer and Hein 2017).

In our empirical analysis, we use stock market capitalization and trading volumes as proxies for the financialization of capital markets and the emergence of shareholder models of corporate governance. Market capitalization and trading volumes are reasonable indicators of the extent to which publicly traded firms face pressures to orient their business practices around efforts to increase returns to shareholders (Barker 2010; Meyer Forthcoming). For the countries in our sample, market capitalization increased more than four-fold (from 18 to 83 percent of GDP) and trading volume by 15 -fold (from four to 60 percent of GDP) over the years examined in our study (World Bank 2016a). We hypothesize that publicly traded firms, as they become more beholden to powerful equity investors, must restructure labor relations in ways that reduce headcounts and eliminate higher-cost unionized labor. We also test whether this effect varies across different types of capitalism, as suggested by Jackson, Höpner, and Kurdelbusch (2006). 


\section{Financial Deregulation and Capital Mobility}

A related linkage is the deregulation of finance and the rise of globally oriented investors. We note that changes to corporate ownership and governance coincided with the deregulation and global integration of financial systems in many advanced capitalist countries. During the post-war era, the international financial system limited crossborder capital flows to foreign direct investments, with the intent of bolstering economic stability and national policy autonomy (Jacoby 2008; Helleiner 1995). However, economic problems in the 1970s prompted a rollback of regulatory constraints and a push toward financial sector deregulation more generally. Some states pursued financial sector liberalization and global integration not as a means of providing liquidity to the "real economy," but as an engine of economic growth in its own right (Crotty 2005; Durand 2017; Helleiner 1995; Lapavitsas 2014). Crucially, states also propelled this aspect of financialization via attempts to address rising public debt and growing current account deficits and - in Europe - through the creation of the Economic and Monetary Union (EMU) (Streeck 2014). Overall, the visible hand of government drove numerous regulatory changes, such as abandoning capital controls on foreign exchange and derivatives trading; loosening restrictions on the international buying and selling of domestic equity; lowering bank liquidity ratios; legalizing hedge funds; and reforming pension funds and stock market legislation to boost new equity investment (Guttman 2016; Peters 2011).

Consequently, financial firms and institutional investors now enjoy significant freedom to operate outside of their national borders. Clearly, this is an important feature of globalization, but we believe it also characterizes financialization, because without the free movement of capital, financial development would be severely hampered and the options available to equity investors severely limited. Indeed, reflecting these changes, inward flows of portfolio investment increased across our sample of 18 countries from a meager two percent of GDP in the early 1970s to a massive 75 percent of GDP by 2012 (World Bank 2016a).

Importantly, we contend that through this second channel of financialization globally oriented finance has sought to overturn long-established business practices, including those that help to sustain organized labor. For example, institutional investors can take assertive roles in their search for short-term profits and capital gains, jettisoning old managerial teams and corporate boards and launching restructuring 
initiatives that create immediate value for shareholders (Ahmadjian and Robbins 2005; Batt and Appelbaum 2014). Furthermore, globally oriented finance can push for new strategic initiatives, such as undertaking mergers and acquisitions and creating global supply chains (Coe and Wai-Chung Yeung 2015; Milberg and Winkler 2013). Both activities may result in layoffs and the shedding of unionized workers in particular (Durand 2017; Morgan 2014).

Clearly, there are limits to finance's ability to force corporate change (Bulfone 2017; Maxfield, Winecoff, and Young 2017), but we believe that the liberalization and globalization of finance increases the degree to which non-financial firms must heed the interests of globally oriented investors. To explore this idea empirically, we examine the magnitude of inward portfolio flows and the liberalization of legal restrictions on capital mobility. We hypothesize that these factors put downward pressure on union density.

\section{Financial Sector Growth and the Reallocation of Labor}

Third, we consider the growing use of financial activities by non-financial firms and how this may affect employment relations and opportunities for unionized employment. In contrast to older models of corporate operations, where firms pursued profits by expanding and improving their core lines of business, financial models of business encourage executives to view their firms as an assemblage of assets whose returns can be maximized through various strategies, including mergers, acquisitions, divestitures, and downsizing (Batt and Appelbaum 2013; Lapavitsas 2014). This leads non-financial firms to heighten their engagement in financial activities-such as derivative trading, leasing, and lending-and to increase their holdings in financial assets (Krippner 2011; Orhangazi 2008).

Importantly, under this business model, the management of financial assets can supplant traditional corporate activities that support unionized employment (Cobb 2016; Duménil and Lévy 2011; Durand 2017). In the United States and Canada, corporations have increased their holdings of financial assets relative to productive assets, and in many cases the income generated from financial holdings has increased significantly (Brennan 2014; Krippner 2011). Similarly, in the United States, the United Kingdom, and France, financial payments made by non-financial firms have grown while fixed capital formation has declined, creating a situation in which finance "crowds out" physical investment and potentially undermines opportunities for unionized employment (Durand 2017; Orhangazi 2008). Furthermore, firms use financial services 
not just to facilitate their normal business operations, but to buy back stock and invest in other financial assets (Milberg and Winkler 2013), causing the financial sector to expand.

We emphasize that these business strategies begin to unhinge corporate profitability from unionized types of employment. In general, this amounts to firms substituting financial activities for the production of tangible goods and services-an outcome that should increase employment in the financial sector but decrease employment in non-financial sectors. Such trends were particularly noticeable in the aftermath of the financial crisis, when many firms invested cash holdings in financial assets rather than core operations (Baker 2017; Detzer and Hein 2014; Stanford 2011). Given that workers overseeing financial activities are rarely unionized, we hypothesize that growth in the financial sector is associated with declining union density.

\section{Corporate Debt and Workforce Reduction}

Growing corporate indebtedness is a fourth linkage between financialization and the deunionization of workplaces. Over recent decades, corporate debt has nearly doubled, growing to 72 percent of GDP across major advanced capitalist countries (Dobbs et al. 2015). Such trends reflect new and profitable uses of debt by non-financial firms. For example, corporations may borrow funds not only to expand normal business operations, but to pursue highly financialized activities-such as mergers and acquisitions and stock buybacks (Crotty 2005; Peters 2011). In turn, these financialized activities can heighten share prices, creating immediate capital gains for shareholders, but they may have negative effects on employment relations. Similarly, private equity partnerships often use debt to purchase firms, which they then "restructure" in ways that free cash for future debt repayments (Batt and Appelbaum 2014). Again, such outcomes put unionized jobs at risk (Lin 2016).

Even less speculative uses of debt may undermine union density. Scholarship highlights links between indebtedness and the strategic decisions of firms (Davis 2016). Because firms make investment and hiring decisions based on projections of future revenue and debts, increased debt can have negative implications for employment relations and labor-cost management (Jung and Dobbin 2014). This happens partly because debt obligations, unlike equity, have fixed repayment schedules, which firms must meet regardless of their performance. Additionally, since creditors take precedence over equity investors in terms of making claims on firms' financial 
resources, even relatively low levels of debt can spark conflicts between debt holders and firm managers over business and employment strategies. Case studies of corporate downsizing find correlations between debt levels and employee layoffs (Gittell et al. 2006; Hillier et al. 2007). Similar studies link highly leveraged firms with the adoption of aggressive stances toward concessionary wage bargaining and unions in general (Batt and Appelbaum 2014; Lin 2016).

As suggested above, the negative implications of corporate indebtedness for employment relations are well known on an individual case basis, but systematic panel studies of this topic are limited. To investigate this matter, we examine credit extended to non-financial firms as a proxy for general levels of corporate indebtedness. For our sample of countries, credit extended to non-financial firms increased nearly threefold over recent decades-rising from 54 percent of GDP in 1975 to 152 percent of GDP by 2012 (OECD 2015b; Ferreiro and Gomez 2016). We expect to find links between this surge in indebtedness and declining union membership.

\section{Financialization and Forms of Capitalism}

In the context of our study, theories from comparative political economy anticipate that the effects of financialization on unionized employment may vary across our sample. In particular, the "varieties of capitalism" perspective identifies liberal market economies (LMEs) and coordinated market economies (CMEs) as the principal types of advanced capitalism (Hall and Soskice 2001; Thelen 2014). Institutional differences between these types of capitalism are held to be systematic and enduring due to the path-dependent nature of capitalist development. In LMEs, firms interact with each other and their employees through arms-length transactions on competitive markets, with outcomes being dictated by prevailing market forces. Equity investors often seek immediate returns and may exert significant influence over firm strategy. In such countries, the negative effects of financialization described above are quite plausible.

By contrast, CMEs are characterized by institutions and business practices that alter the ways market forces affect firm behavior (Aguilera and Jackson 2010; Barker 2010; Bulfone 2017). For our study, we note that unions typically enjoy representation on corporate boards (helping them shape business strategy) and usually engage in policy concertation and centralized wage bargaining (helping them shape national economic policy and sectoral wage rates, respectively). These institutionalized 
practices should enable unions to mitigate the worst effects of financialization. Furthermore, corporate governance offers some protection for long-term strategic shareholders, and most firms have substantial blockholders and engage in crossshareholding with strategically aligned firms. These corporate practices may buffer firms from the immediate demands of portfolio investors by providing them with alternative interests when considering how to respond to market and takeover pressures. Overall, these institutions and business practices should limit the ability of finance capital to restructure employment relations to their advantage (see Jackson, Höpner, and Kurdelbusch 2006).

Toward the end of our study, we examine whether financialization's effect on union density varies between LMEs and CMEs. Our expectation is that financialization puts downward pressure on union density across our sample, but that the specific channels through which this occurs may vary between types of advanced capitalism. In particular, we expect that the financialization of capital markets decisively shapes unionized employment in LMEs, but that financial sector expansion may be more important in CMEs due to its rapid enlargement across the EU in the 1990s and continued growth in the 2000s.

\section{DATA AND METHODS}

\section{Sample}

To test our arguments about financialization's negative effect on organized labor, we collect annual observations on union membership, financialization, and numerous control variables for 18 advanced capitalist countries from 1970 to 2012 . The 18 countries are Australia, Austria, Belgium, Canada, Denmark, Finland, France, Germany, Ireland, Italy, Japan, the Netherlands, New Zealand, Norway, Sweden, Switzerland, the United Kingdom, and the United States. Combining the cross-sectional and temporal dimensions of the data yield 774 observations per variable $(t=43 \times n=$ 18), but missing data and first differencing reduce the number of complete observations to 719 for our baseline model. Some financialization variables begin after 1975 , further reducing the number of observations for effected models.

\section{Main Variables}


Our dependent variable is the percentage of wage and salary earners belonging to unions. This measure includes both private and public sector workers, but excludes union members who are self-employed, retired, unemployed, or otherwise outside the workforce. The data for this widely used measure of union density comes from Visser (2015). We consider using data on private sector unionism, but these data are significantly limited for the countries and years comprising our sample. ${ }^{\mathbf{1}}$

We measure financialization with four variables, which together capture the size, structure, and activities of the financial sector and the different channels through which financialization can reshape firms and labour markets. Our first variable, stock market index, gauges financialization of domestic capital markets. It combines "stock market capitalization" (market value of outstanding shares listed on domestic exchanges per GDP) and "stock trading activity" (market value of stocks sold on domestic exchanges per GDP). Higher market capitalization should increase pressure on firms to generate returns for shareholders, and higher trading activity should correspond to a more active shareholder model of governance. Both outcomes, we contend, heighten pressure on firms to restructure their labor relations systems in ways that benefit external investors. We combine these two measures into an index by converting them to z-scores, summing them, and dividing by two. Data are developed by World Federation of Exchanges and made available by the World Bank (2016a). Unfortunately, the first observations begin in 1975 for most countries and not until the mid-1980s for others (specifically, Finland, Ireland, Italy, New Zealand, Norway, and Switzerland).

Next, inward portfolio index is a composite variable combining de facto and de jure measures of foreign portfolio investment (FPI). Although FPI is associated with globalization, we contend that a thorough understanding of financialization must consider foreign capital flows. Unlike foreign direct investment (FDI), which entails the direct ownership and management of foreign businesses or subsidiaries, FPI are financial assets that can be readily bought and sold on stock markets. This gives them shorter investment timeframes, which we suspect intensifies pressure on firms to restructure their employment relations in order to achieve short-term profitability targets (Ahmadjian and Robbins 2005; Lazonick 2011a). Our de facto measure of FPI gauges the market value of all inward portfolio investment as a percentage of GDP. Data 
come from Lane and Milesi-Ferretti (2017). Our de jure measure captures the liberalization of regulatory constraints on cross-border capital flows. Data come from Chinn and Ito (2016), who use the International Monetary Fund's Annual Report on Exchange Arrangements and Exchange Restrictions to estimate capital account liberalization. Again, to create an index variable, we combine both measures by converting them to z-scores, summing them, and dividing by two.

We use composite variables for several reasons. First, they help us assess financialization as a more general phenomenon since they aggregate underlying details. Additionally, they often yield greater reliability than individual indicators, especially when the phenomenon under consideration is multifaceted. Third, our stock market index is very similar to the measure of financialization used by Meyer (Forthcoming). Finally, our substantive results are unaffected by this decision, so the parsimony of index variables is preferable. However, for readers wishing to see the underlying detail, we re-run our models after disaggregating our index variables and show the result in Table A1 of the appendix.

Our third financialization variable, financial sector size, gauges the overall scope and development of a country's financial sector. Specifically, it equals value added in finance and insurance as a percentage of value added across the entire economy. Following critical political economy literatures, we expect that financial sector expansion reflects deregulation and the ability of financial markets to appropriate resources away from other parts of the economy and subsequently expand labour markets into areas with lower union and employment protection (Durand 2017; Lapavitsas 2014). Data come from Godechot (2016), who creates the series using the OECD STAN database, version 3, and the EU KLEMS database, version 3. This variable begins in 1970 for all countries, except Switzerland where it begins in 1990.

Lastly, corporate indebtedness measures the book value of outstanding debt held by non-financial corporations as a percentage of GDP. Data come from the Bank of International Settlements (2017). This measure reflects "core debt," which includes loans, debt securities, and similar debt obligations, but excludes liabilities arising from accounts payable, financial derivatives, pensions, and employee stock options. Unfortunately, data are missing from the 1970s for Belgium and France and from the 1970s and 1980s from Ireland, the Netherlands, New Zealand, and Switzerland. We 
consider other measures of indebtedness (e.g. World Bank 2016a), but these include household debt, making them inapplicable to our study.

\section{Control Variables}

Our regression models control for 10 known covariates of union density. Here we aim not to account for all possible determinants of union density, but instead to reduce the chance of model misspecification arising from the omission of important control variables. Our selection of control variables is guided by prominent comparative studies of union density in advanced capitalist countries (Checchi and Visser 2005; Lee 2005; Sano and Williamson 2008; Scruggs and Lange 2002; Vachon, Wallace, and Hyde 2016).

Our baseline model starts with structural economic factors thought to affect union density. First, we control for public sector size, partly because our union density variable includes public sector workers, but also because the public sector varies considerably across our sample. Given the lack of suitable panel data on public sector workforces, we use the public sector's contribution to national economic output as a proxy. It measures the value of all goods and services produced by government (at all levels), but excludes cash transfers for social welfare payments and debt repayments. Figures are expressed as a percentage of GDP. Second, we control for trade opennessthe value of imports and exports as a percentage of GDP-because exposure to global markets in tradable goods may impede unionization. Data for both variables come from the Penn World Table (Feenstra, Inklaar, and Timmer 2015). ${ }^{2}$ Third, we control for industrial employment, because the industrial sector is highly unionized but shrinking in most countries. This measure equals the percentage of the national workforce employed in the industrial sector, with the industrial sector including manufacturing, mining, construction, oil and gas extraction, and similar activities. Data come from OECD (2015a).

We also control for various political forces and labor market institutions. Cumulative left cabinet seats measures the long-term presence of labor-friendly governments. It equals the share of cabinet seats held by left parties expressed as a cumulative score from 1960 onwards. Note that the Liberals in Canada and the Democrats in the United States are coded as centrist not left. Data come from the 
Comparative Politics Data Set (Armingeon et al. 2017). Centralized wage bargaining captures the level of wage bargaining and the degree of coordination and control within organized labor itself. Higher scores reflect more centralization and more control. Data come from Visser (2015). Ghent is a dummy variable coded "1" for countries where unions administer publically subsided unemployment benefits on behalf of their members. This creates strong incentives for workers to join unions. Ghent countries are Belgium, Denmark, Finland, and Sweden.

We include unemployment and inflation as similar but independent indictors of the business cycle. Data come from OECD (OECD 2015b). Our general expectation is that rising insecurity brought about by macroeconomic problems heightens incentives for workers to join unions, but Checchi and Visser (2005) argue the situation can be more complex. Specifically, they note that unemployment creates some downward pressure on union density by shifting the balance of class power away from workers, thereby making unionization more difficult, and by pushing some union members out of the workforce altogether. However, these effects are weakened in Ghent countries by the structural link between union membership and unemployment benefits. Also, for inflation, they note that the free rider problem lessens the appeal of unions as a means of protecting real wages, especially when bargaining agreements cover unionized and non-unionized workers alike. Hence, the overall theoretical expectations regarding the business cycle are ambiguous, except for the idea that unemployment's effect on union density should vary between Ghent and non-Ghent countries.

Our variable net immigration controls for the possibility that migrant workers may impede unionization, in part by weakening class solidarity (see Lee 2005). Since panel data are limited, we follow Lee (2005) and measure net immigration indirectly by subtracting a country's natural population change (arising from births and deaths) from its overall population change, with the difference attributed to net immigration. Figures are expressed as cumulative scores, so they reflect the stock of migrants within the general population. Data for the calculations come from the World Bank (2016b).

Lastly, we account for historic levels of union strength. This is motivated by Western's (1995) finding that deunionization occurs sooner and more rapidly in countries where union participation is historically weak (see also Sano and Williamson 2008). Using Visser (2015) data, we measure historic union density as a 10-year lag of 
contemporaneous union density. The long lag-period is possible because Visser's data start in 1960 . We expect this variable to be positively signed, indicating that countries with high union densities in the past experience less union decline in the present.

\section{ESTIMATION STRATEGY}

\section{First-Difference Regression}

Using the data and variables described above, we use first-difference regression analysis to model change in union density as a function of change in four financialization variables and 10 control variables. Shown in simple bivariate form in equation (1), our models use Prais-Winsten estimation procedures and panel-corrected standard errors (PCSE) to account for serial correlation, contemporaneous correlation, and heteroscedasticity.

$$
\Delta y_{i t}=b_{1}\left(\Delta x_{i t}\right)+\Delta \varepsilon_{i t}
$$

This modelling strategy deals with several complications associated with panel data. One complication is the likelihood of unobserved heterogeneity (Halaby 2004; Wooldridge 2012, chap. 14). Standard regression techniques assume that the sample's observations are independent, but observations comprising panel data are structurally linked. While panel data allows us to model union density under different market conditions and institutional contexts, it likely introduces unmeasured heterogeneity into our models. If these unmeasured effects are correlated with one or more of the independent variables, standard regression techniques will yield biased and inconsistent parameter estimates. We address this issue by first differencing-i.e. putting each variable into change-score format. This eliminates unmeasured countryspecific effects and makes our estimation strategy consistent with other studies of union density (Lee 2005; Scruggs and Lange 2002).

Importantly, unlike other panel regression techniques, first differencing addresses the issue of "spurious regression" (De Boef and Keele 2008; Wooldridge 2012, chap. 11 and 18). Especially for data with a long time-series such as ours, annual observations can trend over time rather than vary randomly. This creates the potential for "spurious regression," an outcome in which statistically significant findings reflect shared time trends among variables rather than underlying causal relationships. We note that union density in our sample generally trends downward. This may reflect common trends not captured in our model, such as a growing disinclination of people 
to join civil society organizations such as unions (Kollmeyer 2013; Checchi and Visser 2005) or the tendency for market-constraining institutions such as collective bargaining to become liberalized over time (Baccaro and Howell 2011, 2017; Streeck 2009). Given that our financialization variables generally trend upwards, regression analysis conducted in levels instead of first differences may yield spurious results for our study. Indeed, Im-Pesaran-Shin unit-root tests suggest that most of our variablesincluding our union density variable and all of our financialization variables-are nonstationary when measured in levels, but stationary when measured in first differences. ${ }^{3}$

Our models also account for non-i.i.d. errors (Beck and Katz 1995; Plumper, Troeger, and Manow 2005; Wooldridge 2012, chap. 12). Estimation by ordinary least squares assumes the model's errors are independent and identically distributed (i.i.d.), but models using panel data often violate this assumption even after first differencing. Motivated by these concerns, we test whether our model violates these assumptions. Results from post-estimation tests suggest the presence of non-i.i.d. errors. ${ }^{4}$ Consequently, we use Prais-Winsten regression to account for serial correlation (in the form of panel-specific AR(1)) and panel-corrected standard errors (PCSE) to correct for contemporaneous correlation and heteroscedasticity. The models are estimated with Stata $14.2 .^{5}$

\section{Reverse Causation}

We address the possibility of endogeneity bias arising from reverse causation (Halaby 2004, 532-535; Wooldridge 2012, chap. 16). Of particular concern is the possibility that rising stock market capitalization not only contributes to deunionization, as we argue, but may reflect it as well. In other words, stock market capitalization may increase due to higher corporate profits brought about by weakened unions. Similarly, falling union densities may attract inward portfolio investment. If bidirectional patterns of causation are present but not addressed, our regression results could overestimate the effect of financialization on union decline.

Unfortunately, dealing with reverse causation is difficult. The best approach entails the use of instrumental variable (IV) regression, but this requires the identification of suitable instrument variables, which for our study must be uncorrelated with union density but correlated with stock market capitalization or 
inward portfolio investment. We consult the literature on the determinants of stock market capitalization, especially Garcia and Liu (1999), but fail to find a suitable instrument. ${ }^{6}$ Another approach, generalized method of moments (GMM), allows for endogenous covariates, but requires panel data with relatively short temporal dimensions. Since GMM uses lagged levels as instruments for the first-differenced variables, the number of instruments rises rapidly as the temporal periods increase, creating severe over-identification problems for temporally dominant samples such as ours (Roodman 2009). Following Roodman (2006), we experiment with various techniques, but make little progress. ${ }^{7}$

To deal with these issues, we adopt the more limited approach used by Checchi and Visser $(2005,5)$ in their analysis of union density. This approach entails lagging the suspected endogenous independent variables by one year. The logic of this approach is sound-that this year's dependent variable cannot influence last year's independent variable—but its utility is debateable (see Bellemare, Masaki and Pepinsky 2017). Given our lack of suitable instruments and the inapplicability of GMM to our data, we use this more limited approach by lagging our stock market index and portfolio index variables by one year. We do not lag the other financialization variables, because reverse causation is unlikely. For instance, we know of no evidence suggesting that union decline spurs corporate indebtedness.

Nonetheless, despite a clear solution to the possibility of reverse causation, we are confident that our results do not merely reflect endogeneity bias. Foremost, since our stock market index variable includes a measure of trading activity, and since union decline is unlikely to cause trading volumes to rise, our measure of capital market financialization provides some assurance against reverse causation. In fact, we demonstrate this by re-running our analysis using trading activity as the lone proxy for capital market financialization (see Table A1 of the appendix). The results are statistically significant and show that trading activity is negatively related to union density. This suggests that our findings reflect more than reverse causation.

\section{Alternative Estimation Strategy}

As a robustness check, we re-estimate our parameters with an error correction model (ECM). This technique is increasingly popular in the social sciences (De Boef and 
Keele 2008), albeit disagreement exists over its suitability beyond conditions of strict cointergation (Grant and Lebo 2016). In using an ECM, we follow other studies of union density (see Checchi and Visser 2005; Vachon, Wallace, and Hyde 2016). To account for the panel structure of our data, we adapt the standard ECM specification by including country dummy variables (controlling for unmeasured fixed effects) and panelclustered robust standard errors (controlling for serial correlation and heteroscedasticity).The results from this alternative estimation strategy broadly support our substantive conclusions (see Table A2 in the appendix).

\section{RESULTS}

We begin our analysis with a set of bivariate models (Table 1) and then introduce a set of multivariate models, which include the full battery of control variables (Table 2). Organizing our analysis in this manner allows us to make maximum use of our data (via the bivariate models), and to gain more a varied empirical perspective on our subject matter (by comparing the bivariate and multivariate models). For all models, the independent variables are converted to z-scores to facilitate comparison. As shown below, both sets of models yield similar results.

\section{[Insert Table 1 here]}

Model 1 assesses the bivariate relationship between our stock market index and union density. This index variable, which measures market capitalization and trading volumes, rose across our sample, especially from the mid-1990s onwards, but important cross-national differences are evident. In particular, the United Kingdom and the United States exhibited steady and prominent growth in the stock market index from the 1980s onward, but countries such as Austria, Germany, and Italy experienced more modest growth. We argue that firms embedded in expanding capital markets must pay particular attention to their share price as the ultimate arbitrator of their success. Quite conceivably, the resulting focus on "shareholder value" prods firms to take more adversarial positions toward organized labor, causing union density to drop. Importantly, results from Model 1 are consistent with this argument, as the parameter estimate for stock market index is negative and statistically significant.

Next, Model 2 examines the effect of inward portfolio investment on union density. Recall that during the post-war era most countries maintained strict controls 
over cross-border portfolio investment, but in the late-1970s and early 1980s most countries began liberalizing these controls. In effected countries, this resulted in rising inflows of portfolio investment, which we suspect not only created new sources of financing for domestic firms, but also compelled many firms to redouble efforts to boost returns for foreign investors. In turn, this called into question longstanding social norms governing employment relations, ultimately creating a less hospitable environment for organized labor. Results from Model 2 are consistent with this argument as they show a negative and statistically significant association between inward portfolio index and union density.

We consider two other measures of financialization. First, Model 3 examines growth in the financial sector as a whole. Our expectation is that financial sector expansion leads firms to redirect economic resources away from uses that traditionally support unionized employment. However, Model 3 provides only limited support for this view, as the parameter estimate for financial sector size is negative but just statistically significant. Next, Model 4 examines links between corporate indebtedness and union decline. Contrary to our expectations, we find little evidence that rising corporate debt influences labor relations, as the parameter estimate for corporate indebtedness is small and statistically insignificant by a wide margin. This may reflect the ability of firms to use debt in selective ways, with only some ways reducing unionized employment, but other factors may be at play as well. We discuss this issue in the conclusion.

\section{[Insert Table 2 about here]}

Table 2 introduces our baseline model and proceeds in a stepwise fashion to examine how change in four measures of financialization affect change in union density. As expected, the results from the baseline model indicate that a broad range of market and institutional forces are important determinants of union density (Model 5). Notably, all of our parameter estimates exhibit the expected signs and most are statistically significant. In particular, the baseline model confirms that public sector size, industrial employment, left-labor governments, centralized wage bargaining, historic union strength, unemployment and the Ghent system are positively associated with union density. By contrast, trade openness, inflation, and immigration are negatively associated with union density. 
Importantly, our substantive conclusions are unaffected by the addition of the baseline variables. When comparing the bivariate models (Models 1-4) to their multivariate counterparts (Model 6-9), the parameter estimates differ in only limited ways. In the multivariate models, the effect of capital market financialization is reduced by one half. This is the largest change. But the effect of inward portfolio investment is reduced only slightly. Both estimates retain their statistical significance. Furthermore, the effect of financial sector size increases slightly and remains statistically significant at the $\mathrm{p}<.10$ level, while the effect of corporate indebtedness becomes even smaller and remains insignificant.

Table 3 provides further insights into financialization's effect on union density. In Model 10, we estimate the effects of the financialization variables simultaneously. This allows us to gauge the effect of each financialization variable under conditions when the other financialization variables and control variables are held constant. Results from this more restrictive specification continue to support our earlier findings. In fact, the parameter estimates for the financialization variables are similar (cf. Model 10 and Models 6-9). This implies that each financialization variable-except corporate indebtedness-exerts an independent and downward effect on union density, above and beyond the effects associated with the other financialization variables and the control variables.

\section{[Insert Table 3 about here.]}

We now turn our attention to the relative effects of financialization. Since our independent variables are measured as z-scores, we can readily gauge the relative magnitude of our parameter estimates by direct comparison. Judging from Model 10, financialization is a substantively meaningful determinant of union density, especially if one sums together the three statistically significant financialization variables (i.e. stock market index, inward portfolio index, and financial sector size). However, financialization is not the most important factor. In absolute terms, its combined effect is smaller than those associated with historic union density, immigration, industrial employment, unemployment and the Ghent system, but similar to or greater than those associated with public sector size, left government seats, trade openness, and centralized wage bargaining. Overall, these results support our argument that financialization is an important but underappreciated cause of union decline. 
Next, Model 11 checks whether our results are unduly affected by countries with historically prominent financial sectors. To make this determination, we re-estimate our model after dropping observations from Switzerland, the United States, and the United Kingdom. Results from this reduced sample are similar to results from the full sample (cf. Models 10 and 11), indicating that the negative effects of financialization adhere beyond highly financialized countries. In fact, the effect of capital market financialization is higher in the reduced sample (Model 10) than in the full sample (Model 11). This provides additional evidence in support of our argument that financialization undermines unionized employment across advanced capitalism.

Finally, we end our analysis by considering whether the effects of financialization vary across different forms of advanced capitalism. Recall that theories of comparative political economy anticipate that unions in CMEs are better positioned to withstand the negative effects of stock market financialization than unions in LMEs. This is because institutions and business practices unique to CMEs should limit the power of finance capital to restructure employment relations to their advantage. We examine this possibility by dividing our sample into two subgroups-one for LMEs (Model 12) and another for CMEs (Model 13) - and re-estimating our full model. Admittedly, this simple division between LMEs and CMEs ignores small but potentially meaningful institutional differences between countries and treats these differences as time-invariant. Indeed, although often used in empirical research, some scholars question this approach on these grounds (see Roberts and Kwon 2017; Streeck 2009; Thelen 2014). Nonetheless, we believe it suffices for our purposes, because we use the LME-CME distinction not as the pillar of our analysis, but more as a control variable. We invite readers to interpret Models 12 and 13 with the aforementioned limitations in mind.

A comparison of Models 12 and 13 indicates that financialization generally diminishes union density in both LMEs and CMEs, but that its negative effects manifest unevenly and through different channels. Consistent with expectations derived from the comparative political economy literature, stock market financialization appears to undermine unionized employment more in LMEs than in CMEs. This is evidenced by the parameter estimate for stock market index, which is considerably larger for LMEs $(b=-$ .393) than for CMEs ( $\mathrm{b}=-.251)$, and by the parameter estimate for inward portfolio index, 
which is nearly twice as large for LMEs ( $b=-.418)$ than for CMEs $(b=-204)$. Note that the statistical significance of these re-estimated parameters declines compared to the full sample, but this may reflect smaller sample size. Overall, results from these reestimated models suggest that unions in CMEs, relative to their counterparts in LMEs, enjoy some protection against the power of capital markets and foreign portfolio investors, but that negative effects manifest in both types of capitalism.

Continuing with these two models, we find that financial sector growth puts downward pressure on union density primarily in CMEs. The parameter estimate for the CMEs sample (Model 13) is larger than the full sample (Model 10) and considerably larger than the LMEs sample (Model 12). For the latter, the estimated effect is close to zero and statistically insignificant, signifying that financial sector expansion exerts little downward pressure on union density in LMEs. As described in the conclusion, we surmise that this occurred because consumers played a prominent role in financial sector expansion in LMEs, but consumer-driven financialization may have less bearing on labor relations. By contrast, the transition from industrial to financialized capitalism in CMEs occurred later and more abruptly and relied more on firms than consumers, potentially causing problems for unionized workers.

\section{ConCLuSION}

Drawing on a range of social science literatures, this study is among the first to examine the impact of financialization on union density using panel data. Examining 18 advanced capitalist countries over more than four decades, we compare growth in four aspects of financialization to observed trends in union density. We find that financialization operates through several channels and contributes to union decline across our whole sample, but that the specific effects vary between liberal and coordinated forms of advanced capitalism. In particular, we link deunionization to the growing power and scope of capital markets in LMEs, but find this factor has more limited effects in CMEs. Yet, for this latter form of capitalism, financial sector expansion seems relatively more important. Certainly, these findings underscore how the institutional composition of national economies may shape and deflect some of the broader impacts of financialization, but they also begin to challenge core elements of the varieties of capitalism framework, insofar as they demonstrate that the negative 
effects of financialization hold across countries and across the different models of capitalism (c.f. Jackson, Höpner, and Kurdelbusch 2006).

Indeed, our results suggest that financialization, as a general phenomenon, functions in ways that liberalize labor market institutions and eliminate unionized workers. This happens, we contend, because financialization pressures firms to reduce their payrolls, especially high-paid unionized workers, and because it reshapes the capital accumulation process in ways that redirect economic activity away from productive investment and unionized workforces. Although the particular mechanisms vary across types of capitalism, we observe a general tendency for financialization to reduce unionization and undermine the ability of workers to bargain collectively. This, of course, has pronounced implications for our understanding of labor relations, inequality, and social mobility. It also speaks to sociological thinking about institutional change. In this way, our work dovetails with recent literature on liberalization and the impacts of finance and neoliberalism on inequality and labor markets (see, e.g., Durand 2017; Dumenil and Levy 2011; Godechot 2016; Streeck 2009, 2014; Thelen 2014).

We anticipated most but not all of our findings. One unexpected finding relates to corporate indebtedness and its impact on union density. Here we anticipated that increased corporate indebtedness lowers union density by pressuring firms to restructure labor relations in ways that free resources for debt repayment and uses unrelated to unionized work. However, our regression models provide little support for this idea. Clearly, in some instances, firms use debt in ways that sustain and expand business operations, potentially helping to support unionization. Yet other uses, such as leveraged buyouts, should generate the negative effects on unionization we anticipated. Unfortunately, our corporate indebtedness data cannot make such distinctions regarding the end use of debt, and our FD regression models capture annual changes in debt, but not total levels of debt. Regarding the latter point, perhaps the overall levels of debt, rather than incremental increases, exert influence over labor relations, but we miss this outcome due to our FD regression models. Clearly, this merits further research.

Another unexpected finding relates to financial sector expansion. Here we theorized that financial sector expansion generally shifts investment and economic activity away from uses that traditionally support unionized employment, but we only find evidence of this occurring in CMEs. Regrettably, we lack a thorough explanation for this anomaly, but two possible explanations seem promising. First, consumers in LMEs 
played a pivotal role in financial sector expansion through their purchase of mortgages, home equity loans, student loans, credits cards, mutual funds, and other financial services (Fligstein and Goldstein 2015). While this clearly affects household indebtedness, it may not exert influence over labor relations. By contrast, non-financial firms in CMEs played a leading role in financial sector expansion through their increased use of financial services (Van Treeck 2009). Quite conceivably, this type of financial sector expansion should affect unionization in the ways we predicted and the regression results confirmed.

Second, there is an issue of timing. LMEs have always had relatively larger financial sectors than CMEs, but this distinction began to change in the 1990s and 2000s with the advent of the Euro and new stability and growth pacts, both of which prompted financial sector expansion in many European countries (Durand 2017; Lapavitsas 2014). In this way, financial sector expansion was more abrupt and possibly more disruptive to unionization in CMEs than LMEs. Clearly, more research is needed on this issue, but the aforementioned ideas offer potential starting points.

Similarly, future research may wish to address other aspects of financialization. Although the topic is well studied (e.g. Epstein 2015), much of the financialization literature focuses on the United States or contrasts the US experience with the supposedly less-financialized capitalism of Western Europe. Much of this work conceptualizes financialization as a single process, but along with other scholars, we contend that it operates through a number of distinct but interrelated channels (see Durand 2017; Lapavitsas 2014). Our study constructs four distinct measures of financialization, but further research may wish to examine other possible forms of financialization or develop more detailed analyses of the dimensions examined here.

Lastly, the relationship between financialization and globalization should be explored further. Several studies note that financialization, outsourcing, and global production networks are interconnected (Coe and Wai-Chung Yeung 2015; Durand 2017; Milberg and Winkler 2013). In this vein, we conceptualized the globalization of financial markets and financialization more generally as overlapping phenomena. But more theoretical and empirical research is required to untangle this complex relationship and determine its effects on national economic outcomes. 


\section{END NOTES}

1. Data on private sector union density are available from Visser (2015), but significantly limited for our sample. Thus, we use the standard measure of union density, but control for public sector size to offset the inclusion of public sector workers.

2. We draw on four series from the Penn World Table. Public sector size is "csh_g" (government's share of national consumption). Trade openness is the sum of "csh_m" (imports' share of national consumption) plus "csh_x" (exports' share of national consumption) divided by "cgdpe" (expenditure side GDP).

3. We use Stata's xtunitroot ips command to assess the null hypothesis that the various series contain a unit-root (i.e. are non-stationary). Results suggest that our dependent variable, the financialization variables, and most control variables are non-stationary in levels.

4. We conduct three post-estimation tests on Model 10. (1) A Wooldridge test, performed with the xtserial command, assesses a null hypothesis that the errors do not exhibit first-order serial correlation. The results (prob $>F=0.000$ ) suggests the likely presence of serial correlation. (2) A modified version of the Breusch-Pagan test, performed with the xttest2 command, assesses a null hypothesis that the errors are independent across countries. The results (prob $>\chi 2=0.000$ ) suggest the presence of contemporaneously correlated errors. (3) A modified version of the Wald test, performed with the xttest 3 command, assesses a null hypothesis that the errors have a common variance across panels. This null hypothesis is rejected (prob $>\chi 2=0.000$ ).

5. We estimate our models with the following Stata command: xtpcse d.(dependent variable, independent variable list), correlation(psar1). The "d." implements first differencing.

6. We identify "annual trading activity" as a possible instrument for "stock market capitalization," but find both variables are correlated with union density. For this reason, we combine them into a single index. 
7. We use Roodman's (2006) "xtabond2" command and experiment with ways to overcome the "too many instruments" problem (Roodman 2009). First, following Roodman (2006), we reduce the number of GMM-style instruments by collapsing the matrix of instruments into a single column and by limiting the number of lags used as instruments. However, our instrumented variables remain over-identified (i.e. Sargan test $p$-value $=.000)$. Second, we drastically reduce the temporal dimension of our panel data by limiting observations to once every five years (i.e. 1970, 1975, 1980...2010). This helps but insufficiently ameliorates the problem (i.e. Sargan test p-value $=.110$ ).

\section{About The Authors}

Christopher Kollmeyer is a Senior Lecturer of Sociology at the University of Aberdeen. His research examines large-scale change in the social structures and political economies of advanced capitalist countries and how this affects a range of outcomes, including income inequality, union participation, and democratic politics. His work appears in numerous journals including the American Journal of Sociology, European Sociological Review, International Journal of Comparative Sociology, and Social Forces.

John Peters is an Associate Professor of Labour Studies at Laurentian University. His research focuses on economic globalization, inequality, and labour market deregulation. He has recently completed a manuscript entitled Jobs with Inequality: Financialization, Post-Democracy, and Labour Market Deregulation in Canada (forthcoming University of Toronto Press) and is currently examining the impacts of austerity as well as the policies required to improve jobs and employment. 


\section{REFERENCES}

Aguilera, Ruth V, and Gregory Jackson. 2010. "Comparative and International Corporate Governance." Academy of Management Annals 4 (1):485-556.

Ahmadjian, Christina L, and Gregory E Robbins. 2005. "A Clash of Capitalisms: Foreign Shareholders and Corporate Restructuring in 1990s Japan." American Sociological Review 70(3):451-471.

Armingeon, Klaus, Virginia Wenger, Fiona Wiedemeier, Christian Isler, Laura Knöpfel, David Weisstanner, and Sarah Engler. 2017. Comparative Political Dataset 19602015. Berne, CH: University of Berne.

Baccaro, Lucio, and Chris Howell. 2011. "A Common Neoliberal Trajectory: The Transformation of Industrial Relations in Advanced Capitalism." Politics and Society 39(4):521-563.

- - - 2017. European Industrial Relations: Trajectories of Neoliberal Transformation. New York, NY: Cambridge University Press.

Baker, Dean. 2017. Rigged: How Globalization and the Rules of the Modern Economy Were Structured to Make the Rich Richers. Washington, DC: Center for Economic and Policy Research.

Bank for International Settlements. 2017. Table 4: Total Credit to Non-Financial Corporations (core debt). In BIS Statistics. Basel, Switzerland.

Barker, Roger M. 2010. Corporate Governance, Competition, and Political Parties : Explaining Corporate Governance Change in Europe: Oxford: Oxford University Press.

Batt, Rosemary, and Eileen Appelbaum. 2013. "The Impact of Financialization on Management and Employment Outcomes." Upjohn Institute Working Paper 13(191). Available at http://research.upjohn.org/up_workingpapers/191/ 2014. Private Equity at Work: When Wall Street Manages Main Street. New York, NY: Russell Sage Publications.

Beck, Nathaniel, and Jonathon N. Katz. 1995. "What To Do (and not to do) With TimeSeries Cross-Section Data." American Journal of Political Science 89(3):634-647.

Bellemare, Marc F., Takaaki Masaki, and Thomas B. Pepinsky. 2017. "Lagged Explanatory Variables and the Estimation of Causal Effect." Journal of Politics 79(3): 949-963.

Brady, David. 2007. "Institutional, Economic, or Solidaristic? Assessing Explanations for Unionization Across Affluent Democracies." Work and Occupations 34:67-101.

Brennan, Jordan. 2014. The Creation of a Shared Prosperity in Canada: Unions, Corporations, and Countervailing Power. Ottawa, ON: Canadian Centre for Policy Alternatives.

Bulfone, Fabio. 2017. "Insider Job: Corporate Reforms and Power Resources in France, Italy and Spain." Socio-Economic Review 15(2):435-459.

Celik, Serdar, and Mats Isaksson. 2014. "Institutional Investors and Ownership Engagement." OECD Journal: Financial Market Trends 2013 (2):93-114.

Checchi, Daniele, and Jelle Visser. 2005. "Pattern Persistence in European Trade Union Density: A Longitudinal Analysis 1950-1996." European Sociological Review 21 (1):1-21.

Chinn, Menzie, and Hiro Ito. 2016. The Chinn-Ito Index: A Dejure Measure of Financial Openness. http://web.pdx.edu/ ito/Chinn-Ito website.htm.

Cobb, J. Adam. 2016. "How Firms Shape Income Inequality." Academy of Management Review 41(2):324-348. 
Coe, Neil, and Henry Wai-Chung Yeung. 2015. Global Production Networks: Theorizing Economic Development in an Inter-Connected World. New York, Ny: Oxford University Press.

Crotty, James. 2005. "The Neoliberal Paradox: The Impact of Destructive Product Market Competion and 'Modern' Financial Markets on Nonfinancial Corporate Performance in the Neoliberal Era." In G. Epstein, eds., Financialization and the World Economy. Northampton, MA: Edward Elgar.

Cushen, Jean, and Paul Thompson. 2016. "Financialization and Value: Why Labour and the Labour Process Still Matter." Work, Employment \& Society 30(2):352-365.

Darcillon, Thibault. 2015. "How Does Finance Affect Labor Market Institutions? An Empirical Analysis in 16 OECD Countries." Socio-Economic Review 13(3):477-504.

Davis, Gerald F. 2009. Managed by Markets: How Finance Reshaped America. New York, N.Y.: Oxford University Press.

2016. The Vanishing American Corporation. Oakland, CA: Berrett-Koehler.

De Boef, Suzanna, and Luke Keele. 2008. "Taking Time Seriously." American Journal of Political Science 52(1):184-200.

Detzer, Daniel, and Eckhard Hein. 2014. Financialisation and the Financial and Economic Crisis: The Case of Germany. FESSUD Financialisation, Economy, Society and Sustainable Development.

-_- 2017. "Financialisation and Income Distribution." In D. Detzer et al. eds., The German Financial System and the Financial and Economic Crisis. Cham, CH: Springer International Publishing.

Deutsche Bundesbank. 2014. "Ownership Structure in the German Equity Market: General Trends and Changes in the Financial Crisis." In Monthly Report. Frankfurt, DEU: Deutsche Bundesbank.

Dobbs, Richard, Susan Lund, Jonathan Woetzl, and Mina Mutafchieva. 2015. Debt and (not much) Delveraging. Toronto, ON: McKinsey Global Institute.

Duménil, Gérard, and Dominique Lévy. 2011. The Crisis of Neoliberalism. Cambridge, MA: Harvard University Press.

Durand, Cedric. 2017. Fictitious Capital: How Finance is Appropriating Our Future. New York, N.Y.: Verso.

Epstein, Gerald. 2015. “Financialization: There's Something Happening Here.” Working Paper Series. Amherst, MA: Political Economy Research Institute, University of Massachusetts Amherst.

Feenstra, Robert, Robert Inklaar, and Marcel Timmer. 2015. Penn World Table, version 8.1. (DOI: 10.15141/S5NP4S).

Ferreiro, Jesus, and Carmen Gomez. 2016. "Financialization and the Financial Balance Sheets of Economic Sectors in the Eurozone." In P. Arestis and M. Sawyer, eds., Financial Liberalisation: Past, Present, and Future. New York, NY: Palgrave Macmillan.

Fichtner, Jan, Eelke Heemskerk, and Javier Garcia-Bernardo. 2017. "Hidden Power of the Big Three? Passive Index Funds, Re-concentration of Corporate Ownership, and New Financial Risk." Business and Politics 19:Online.

Fligstein, Neil. 2001. The Architecture of Markets: An Economic Sociology of Twenty-FirstCentury Capitalist Societies. Princeton: Princeton University Press,

Fligstein, Neil, and Taekjin Shin. 2007. "Shareholder Value and the Transformation of the U.S. Economy, 1984-2000." Sociological Forum 22(4):399-424.

Fligstein, Neil, and Adam Goldstein. 2015. "The Emergence of a Finance Culture in American Households, 1989-2007." Socio-Economic Review 13(3): 575-601.

Forhoohar, Rana. 2016. Makers and Takers: The Rise and Fall of American Business. New York, N.Y.: Crown Publishing.

Garcia, Valeriano F, and Lin Liu. 1999. "Macroeconomic Determinants of Stock Market Development. "Journal of Applied Economics 2(1):29-59. 
Gittell, Jody Hoffer, Kim Cameron, Sandy Lim, and Victor Rivas. 2006. "Relationships, Layoffs, and Organizational Resilience: Airline Industry Responses to September 11." Journal of Applied Behavioral Science 42(3):300-329.

Godechot, Olivier. 2016. "Financialization is Marketization! A Study of the Respective Impacts of Various Dimensions of Financialization on the Increase in Global Inequality." Sociological Science 3:495-519.

Gospel, Howard, and Andrew Pendleton. eds. 2005. Corporate Governance and Labour Management: An International Comparison. New York: Oxford University Press.

Gospel, Howard, Andrew Pendleton, and Sigurt Vitols. 2013. Financialization, New Investment Funds, and Labour: An International Comparison. New York: Oxford University Press.

Guttmann, Robert. 2016. Finance-Led Capitalism: Shadow Banking, Re-Regulation, and the Future of Global Markets. New York: Palgrave MacMillan.

Grant, Taylor, and Matthew J Lebo. 2016. "Error Correction Methods with Political Time Series." Political Analysis 24(1):3-30.

Halaby, Charles N. 2004. "Panel Models in Sociological Research: Theory into Practice." Annual Review of Sociology 30: 507-544.

Hall, Peter A., and David Soskice. eds. 2001. Varieties of Capitalism: The Institutional Foundations of Comparative Advantage. New York: Cambridge University Press.

Helleiner, Eric. 1995. "Explaining the Globalization of Financial Markets: Bringing States Back In." Review of International Political Economy 2(2):315-341.

Hillier, David, Andrew Marshall, Patrick McColgan, and Samwel Werema. 2007. "Employee Layoffs, Shareholder Wealth and Firm Performance: Evidence from the UK." Journal of Business Finance \& Accounting 34(3-4):467-494.

Huizinga, Harry, and Lars Jonung. eds. 2005. The Internationalization of Asset Ownership in Europe. New York: Cambridge University Press.

Jackson, Gregory, Martin Höpner, and Antje Kurdelbusch. 2006. “Corporate Governance and Employees in Germany: Changing Linkages, Complementarities, and Tensions." In H. Gospel and A. Pendleton, eds., Corporate Governance and Labour Management: An International Comparison, Oxford: Oxford University Press.

Jacoby, Sanford M. 2008. "Finance and Labor: Perspectives on Risk, Inequality, and Democracy." Comparative Labor Law \& Policy Journal, 30: 17-65.

Jung, Jiwook. 2014. "Shareholder Value and Workforce Downsizing, 1981-2006." Social Forces 93(4):1335-1368.

Jung, Jiwook, and Frank Dobbin. 2014. "Finance and Institutional Investors." In K. Knorr Cetina and A. Preda, eds., The Oxford Handbook of The Sociology of Finance. New York, NY: Oxford University Press.

Kollmeyer, Christopher. 2018. "Trade Union Decline, Deindustrialization, and Rising Income Inequality in the United States, 1947 to 2015." Research in Social Stratification and Mobility 57:1-10.

------. 2013. "Who Joins Trade Unions: Testing New Sociological Explanations." Comparative Sociology 12(4): 548-574.

Krippner, Greta R. 2011. Capitalizing on Crisis: The Political Origins of the Rise of Finance. Cambridge, MA: Harvard University Press.

Lane, Philip, and Maria Milesi-Ferretti. 2017. International Financial Integration in the Aftermath of the Global Financial Crisis. In IMF Working Paper and Dataset No. 17/15. Washington, DC: IMF.

Lapavitsas, Costas. 2014. Profiting Without Producing: How Finance Exploits Us All. New York, NY: Verso. 
Lazonick, William. 2011a. "From Innovation to Financialization: How Shareholder Value Ideology is Destroying the US Economy." Chap. 24 in Handbook of the Political Economy of Financial Crises, ed. by Martin Wolfson and Gerald Epstein. Oxford: Oxford University Press.

-_- 2011b. Sustainable Prosperity in the New Economy? Business Organization and High-Tech Employment in the United States. Kalamazoo, MI: W. E. Upjohn Institute for Employment Research.

Lazonick, William, and Mary O'Sullivan. 2000. "Maximizing Shareholder Value: A New Ideology for Corporate Governance." Economy and Society 29(1):13-35.

Lee, Cheol-Sung. 2005. "International Migration, Deindustrialization, and Union Decline in 16 Affluent OECD Countries, 1962-1997." Social Forces 84(1):71-88.

Levine, Robert. 1997. "Financial Development and Economic Growth: Views and Agenda." Journal of Economic Literature 35(2):688-726.

Lin, Ken-Hou. 2016. "The Rise of Finance and Firm Employment Dynamics." Organization Science 27(4):972-988.

Lin, Ken-Hou, and Donald Tomaskovic-Devey. 2013. "Financialization and US income Inequality, 1970-2008." American Journal of Sociology 118(5): 1284-1329.

Maxfield, Sylvia, W Kindred Winecoff, and Kevin L Young. 2017. "An Empirical Investigation of the Financialization Convergence Hypothesis." Review of International Political Economy 24(6):1-26.

Meyer, Brett. Forthcoming. "Financialization, Technological Change, and Trade Union Decline." Socio-Economic Review On-line:1-26.

Milberg, William, and Deborah Winkler. 2013. Outsourcing Economics: Global Value Chains in Capitalist Development. New York, NY: Cambridge University Press.

Morgan, Glenn. 2014. "Financialization and the Multi-National Corporation." Transfer 20 (2):183-197.

Murphy, Caroline, and Thomas Turner. 2014. "Organising Non-Standard Workers: Union Recruitment in the Irish Care Sector." Industrial Relations Journal 45 (5):373-388.

Observatoire de l'Epargne Europeene, and INSEAD OEE Data Services. 2013. Who Owns the European Economy? Evolution of the Ownership of EU-listed Companies between 1970 and 2012. Edited by F. S. U. Group. Brussels, BE: European Commission.

OECD. 2015a. Employment and Labour Force Statistics. Paris, FR.

- - . 2015b. OECD Economic Outlook: Statistics and Projections. Paris, FR.

O’Farrell, Rory. 2010. "The Effect of International Trade on Trade Union Density." European Trade Union Institute Working Paper. European University Institute.

Orhangazi, Özgür. 2008. "Financialisation and Capital Accumulation in the NonFinancial Corporate Sector: A Theoretical and Empirical Investigation on the US Economy, 1973-2003." Cambridge Journal of Economics 32(6): 863-86.

Peters, John. 2011. "The Rise of Finance and the Decline of Organised Labour in the Advanced Capitalist Countries." New Political Economy 16(1): 73-99.

Plumper, Thomas, Vera Troeger, and Phiiip Manow. 2005. "Panel Data Analysis in Comparative Politics: Linking Method to Theory." European Journal of Political Research 44(2):327-354.

Roberts, Anthony, and Roy Kwon. 2017. "Finance, Inequality and the Varieties of Capitalism in Post-industrial Democracies." Socio-Economic Review 15(3):511538.

Roodman, David. 2006. "How to do xtabond2: An Introduction to Difference and System GMM in Stata." Working Paper 103. Washington, D.C.: Center for Global Development. 
2009. "A Note on the Theme of Too Many Instruments." Oxford Bulletin of Economics and Statistics 71(1): 135-158.

Sano, Joelle, and John Williamson. 2008. "Factors Affecting Union Decline in 18 OECD Countries and Their Implications for Labour Movement Reform." International Journal of Comparative Sociology 49 (6):479-500.

Scruggs, Lyle, and Peter Lange. 2002. "Where Have All the Members Gone? Globalization, Institutions, and Union Density." Journal of Politics 64(10):126-153.

Slaughter, Matthew J. 2007. "Globalization and Declining Unionization in the United States." Industrial Relations: A Journal of Economy and Society 46(2):329-346.

Stanford, Jim. 2011. Having their Cake and Eating it Too. Business Profits, Taxes, and Investment in Canada: 1961 through 2010. Ottawa: Canadian Centre for Policy Alternatives.

Streeck, Wolfgang. 2009. Re-Forming Capitalism: Institutional Change in the German Political Economy. Oxford: Oxford University Press.

- - . 2014. Buying Time. The Delayed Crisis of Democratic Capitalism. New York: Verso.

Thelen, Kathleen. 2014. Varieties of Liberalisation and the New Politics of Social Solidarity. New York: Cambridge University Press.

Thompson, Paul. 2013. "Financialization and the Workplace." Work, Employment \& Society 27(3):472-488.

Tomaskovic-Devey, Donald, and Ken-Hou Lin. 2011. "Income Dynamics, Economic Rents, and the Financialization of the US Economy." American Sociological Review 76(4): 538-559.

Vachon, Todd, Michael Wallace, and Allen Hyde. 2016. "Union Decline in a Neoliberal Age." Socius: Sociological Research for a Dynamic World 2 (online).

Van Treeck, Till. 2009. “The Political Economy Debate on 'Financialization'-A Macroeconomic Perspective." Review of International Political Economy 16(5): 907-944.

Visser, Jelle. 2015. Database on Institutional Characteristics of Trade Unions, Wage Setting, State Intervention, and Social Pacts in 34 Countries between 1960-2014 (version 5.0). Amsterdam Institute for Advanced Labour Studies (AIAS). Amsterdam: University of Amsterdam.

Western, Bruce. 1995. "A Comparative Study of Working-Class Disorganization: Union Decline in Eighteen Advanced Capitalist Countries." American Sociological Review 60(2):179-201.

- - - 1997. Between Class and Market: postwar unionization in the capitalist democracies. Princeton, N. J: Princeton University Press.

Wooldridge, Jeffrey. 2012. Introductory Econometrics: A Modern Approach. 5th ed. Mason, $\mathrm{OH}$ : South-Western.

World Bank. 2016a. Global Financial Development (database). Wasington, D.C.: The World Bank.

——_. 2016b. World Development Indicators (database). Wasington, D.C.: The World Bank. 
Table 1. Bivariate Models of Financialization on Union Density

\begin{tabular}{lllll}
\hline \hline & $(1)$ & $(2)$ & $(3)$ & $(4)$ \\
\hline Financialization variables & & & & \\
Stock market index $(\mathrm{t}-1)$ & $-.416^{* * *}$ & & & \\
& $(.087)$ & & & \\
Inward portfolio index (t-1) & & $-.670^{* * *}$ & & \\
& & $(.186)$ & & \\
Financial sector size & & $-.136 \dagger$ & \\
& & & $(.083)$ & -.122 \\
Corporate indebtedness & & & & $(.283)$ \\
& 18 & 18 & 18 & 18 \\
\hline Number of countries & 627 & 658 & 703 & 681 \\
Number of observations & .047 & .031 & .019 & .007 \\
R-squared & & & & \\
\hline \hline
\end{tabular}

Note: All variables are first differenced. Independent variables measured as z-scores.

Estimation by Prais-Winsten regression. Panel corrected standard errors in parentheses.

$\dagger=\mathrm{p}<.10 ;^{*}=\mathrm{p}<.05 ;^{* *}=\mathrm{p}<.01 ;^{* * *}=\mathrm{p}<.001$. 
Table 2. Multivariate Regression Models of Financialization on Union Density

\begin{tabular}{|c|c|c|c|c|c|}
\hline & (5) & (6) & (7) & (8) & (9) \\
\hline \multicolumn{6}{|l|}{ Baseline model } \\
\hline Public sector size & $\begin{array}{l}.626^{* *} \\
(.233)\end{array}$ & $\begin{array}{l}.429^{*} \\
(.204)\end{array}$ & $\begin{array}{l}.597^{* *} \\
(.189)\end{array}$ & $\begin{array}{l}.727^{* * *} \\
(.208)\end{array}$ & $\begin{array}{l}.588^{* *} \\
(.195)\end{array}$ \\
\hline Industrial employment & $\begin{array}{l}2.156^{* * *} \\
(.483)\end{array}$ & $\begin{array}{l}1.731^{* * *} \\
(.423)\end{array}$ & $\begin{array}{l}2.354^{* * *} \\
(.374)\end{array}$ & $\begin{array}{l}2.407^{* * *} \\
(.479)\end{array}$ & $\begin{array}{l}2.049^{* * *} \\
(.412)\end{array}$ \\
\hline Trade openness & $\begin{array}{l}-.303 \\
(.298)\end{array}$ & $\begin{array}{l}-.546^{*} \\
(.247)\end{array}$ & $\begin{array}{l}-.205 \\
(.254)\end{array}$ & $\begin{array}{l}-.184 \\
(.267)\end{array}$ & $\begin{array}{l}-.142 \\
(.273)\end{array}$ \\
\hline Left cabinet seats (cum.) & $\begin{array}{l}1.803 \dagger \\
(.985)\end{array}$ & $\begin{array}{l}.719 \\
(.911)\end{array}$ & $\begin{array}{l}2.051^{*} \\
(.832)\end{array}$ & $\begin{array}{l}2.044^{*} \\
(.963)\end{array}$ & $\begin{array}{l}1.971 * \\
(.889)\end{array}$ \\
\hline Centralized wage bargaining & $\begin{array}{l}.226 \\
(.387)\end{array}$ & $\begin{array}{l}.106 \\
(.229)\end{array}$ & $\begin{array}{l}.225 \\
(.227)\end{array}$ & $\begin{array}{l}.288 \\
(.365)\end{array}$ & $\begin{array}{l}.148 \\
(.226)\end{array}$ \\
\hline Inflation & $\begin{array}{l}-1.646 \dagger \\
(.968)\end{array}$ & $\begin{array}{l}-.958 \\
(.860)\end{array}$ & $\begin{array}{l}-1.882^{*} \\
(.823)\end{array}$ & $\begin{array}{l}-1.749 \dagger \\
(.953)\end{array}$ & $\begin{array}{l}-1.471^{*} \\
(.678)\end{array}$ \\
\hline Unemployment (non-Ghent) & $\begin{array}{l}1.331^{* * *} \\
(.238)\end{array}$ & $\begin{array}{l}1.292^{* * *} \\
(.212)\end{array}$ & $\begin{array}{l}1.399^{* * *} \\
(.192)\end{array}$ & $\begin{array}{l}1.399 * * * \\
(.247)\end{array}$ & $\begin{array}{l}1.372^{* * *} \\
(.173)\end{array}$ \\
\hline Unemployment (Ghent) & $\begin{array}{l}1.831^{* * *} \\
(.279)\end{array}$ & $\begin{array}{l}1.453^{* * *} \\
(.260)\end{array}$ & $\begin{array}{l}1.943^{* * *} \\
(.256)\end{array}$ & $\begin{array}{l}1.943^{* * *} \\
(.283)\end{array}$ & $\begin{array}{l}1.760^{* * *} \\
(.266)\end{array}$ \\
\hline Net immigration & $\begin{array}{l}-1.528 \dagger \\
(.995)\end{array}$ & $\begin{array}{l}-2.927^{* * *} \\
(.874)\end{array}$ & $\begin{array}{l}-1.394 \dagger \\
(.759)\end{array}$ & $\begin{array}{l}-1.245 \dagger \\
(.724)\end{array}$ & $\begin{array}{l}-2.330^{* * *} \\
(.628)\end{array}$ \\
\hline Historic union density & $\begin{array}{l}1.424^{*} \\
(.685)\end{array}$ & $\begin{array}{l}1.233^{*} \\
(.604)\end{array}$ & $\begin{array}{l}1.546^{* *} \\
(.564)\end{array}$ & $\begin{array}{l}1.682^{*} \\
(.683)\end{array}$ & $\begin{array}{l}1.666^{* *} \\
(.524)\end{array}$ \\
\hline Financialization variables & & & & & \\
\hline Stock market index (t-1) & & $\begin{array}{l}-.196^{* *} \\
(.067)\end{array}$ & & & \\
\hline Inward portfolio index (t-1) & & & $\begin{array}{l}-.560^{* * *} \\
(.161)\end{array}$ & & \\
\hline Financial sector size & & & & $\begin{array}{l}-.201 \dagger \\
(.115)\end{array}$ & \\
\hline Corporate indebtedness & & & & & $\begin{array}{l}-.008 \\
(.009)\end{array}$ \\
\hline Number of countries & 18 & 18 & 18 & 18 & 18 \\
\hline Number of observations & 723 & 583 & 658 & 684 & 609 \\
\hline R-squared & .143 & .211 & .174 & .153 & .150 \\
\hline
\end{tabular}

Note: All variables are first differenced. Independent variables measured as z-scores. Estimation by Prais-Winsten regression. Panel corrected standard errors in parentheses. $\dagger=\mathrm{p}<.10 ;^{*}=\mathrm{p}<.05 ;^{* *}=\mathrm{p}<.01{ }^{* * *}=\mathrm{p}<.001$. 
Table 3. Full Regression Model of Financialization on Union Density: Whole Sample and Selected Cases

\begin{tabular}{|c|c|c|c|c|}
\hline & $\begin{array}{l}\text { Full } \\
\text { Sample } \\
(10)\end{array}$ & $\begin{array}{l}\text { Drop CH, } \\
\text { UK, \& US } \\
(11)\end{array}$ & $\begin{array}{l}\text { LMEs } \\
\text { Only } \\
(12) \\
\end{array}$ & $\begin{array}{l}\text { CMEs } \\
\text { Only } \\
(13) \\
\end{array}$ \\
\hline \multicolumn{5}{|l|}{ Baseline model } \\
\hline Public sector size & $\begin{array}{l}.425^{*} \\
(.183)\end{array}$ & $\begin{array}{l}.382^{*} \\
(.177)\end{array}$ & $\begin{array}{l}1.400^{* *} \\
(.501)\end{array}$ & $\begin{array}{l}.375^{\dagger} \\
(.218)\end{array}$ \\
\hline Industrial employment & $\begin{array}{l}1.870^{* * *} \\
(.438)\end{array}$ & $\begin{array}{l}2.098^{* * *} \\
(.533)\end{array}$ & $\begin{array}{l}2.259^{* *} \\
(.866)\end{array}$ & $\begin{array}{l}2.056^{* * *} \\
(.561)\end{array}$ \\
\hline Trade openness & $\begin{array}{l}-.422^{\dagger} \\
(.254)\end{array}$ & $\begin{array}{l}-.414 \\
(.279)\end{array}$ & $\begin{array}{l}-1.181^{*} \\
(.515)\end{array}$ & $\begin{array}{l}-.156 \\
(.281)\end{array}$ \\
\hline Left cabinet seats (cum.) & $\begin{array}{l}.962 \\
(.845)\end{array}$ & $\begin{array}{l}.470 \\
(1.020)\end{array}$ & $\begin{array}{l}.369 \\
(1.441)\end{array}$ & $\begin{array}{l}.960 \\
(1.099)\end{array}$ \\
\hline Centralized wage bargaining & $\begin{array}{l}.148 \\
(.228)\end{array}$ & $\begin{array}{l}.259 \\
(.288)\end{array}$ & $\begin{array}{l}.514 \\
(.304)\end{array}$ & $\begin{array}{l}.127 \\
(.396)\end{array}$ \\
\hline Inflation & $\begin{array}{l}-1.092 \\
(.925)\end{array}$ & $\begin{array}{l}-.753 \\
(1.155)\end{array}$ & $\begin{array}{l}-.647 \\
(1.321)\end{array}$ & $\begin{array}{l}-2.746^{* *} \\
(.926)\end{array}$ \\
\hline Unemployment (non-Ghent) & $\begin{array}{l}1.362^{* * *} \\
(.223)\end{array}$ & $\begin{array}{l}1.485^{* * *} \\
(.281)\end{array}$ & $\begin{array}{l}1.552^{* * *} \\
(.314)\end{array}$ & $\begin{array}{l}.861^{* * *} \\
(.258)\end{array}$ \\
\hline Unemployment (Ghent) & $\begin{array}{l}1.559^{* * *} \\
(.273)\end{array}$ & $\begin{array}{l}1.618^{* * * *} \\
(.285)\end{array}$ & & $\begin{array}{l}1.690^{* * *} \\
(.281)\end{array}$ \\
\hline Net immigration & $\begin{array}{l}-3.434^{* * *} \\
(.113)\end{array}$ & $\begin{array}{l}-3.600^{* * *} \\
(1.135)\end{array}$ & $\begin{array}{l}-5.111^{* * *} \\
(1.031)\end{array}$ & $\begin{array}{l}-1.701 \dagger \\
(1.014)\end{array}$ \\
\hline Historic union density & $\begin{array}{l}1.515^{*} \\
(.633)\end{array}$ & $\begin{array}{l}1.134 \dagger \\
(.711)\end{array}$ & $\begin{array}{l}1.812^{*} \\
(.892)\end{array}$ & $\begin{array}{l}.958 \\
(.692)\end{array}$ \\
\hline \multicolumn{5}{|l|}{ Financialization variables } \\
\hline Stock market index (t-1) & $\begin{array}{l}-.277^{* * *} \\
(.079)\end{array}$ & $\begin{array}{l}-.373^{* *} \\
(.137)\end{array}$ & $\begin{array}{l}-.393^{*} \\
(.178)\end{array}$ & $\begin{array}{l}-.251^{* *} \\
(.092)\end{array}$ \\
\hline Inward portfolio index (t-1) & $\begin{array}{l}-.404^{*} \\
(.171)\end{array}$ & $\begin{array}{l}-.465^{*} \\
(.218)\end{array}$ & $\begin{array}{l}-418^{\dagger} \\
(.238)\end{array}$ & $\begin{array}{l}-.204 \\
(.168)\end{array}$ \\
\hline Financial sector size & $\begin{array}{l}-.216^{*} \\
(.108)\end{array}$ & $\begin{array}{l}-295^{*} \\
(.141)\end{array}$ & $\begin{array}{l}-.063 \\
(.208)\end{array}$ & $\begin{array}{l}-.326^{*} \\
(.154)\end{array}$ \\
\hline Corporate indebtedness & $\begin{array}{l}.001 \\
(.005) \\
\end{array}$ & $\begin{array}{l}.001 \\
(.005) \\
\end{array}$ & $\begin{array}{l}.001 \\
(.005) \\
\end{array}$ & $\begin{array}{l}.001 \\
(.005) \\
\end{array}$ \\
\hline Number of countries & 18 & 15 & 6 & 12 \\
\hline Number of observations & 536 & 458 & 157 & 360 \\
\hline R-squared & .232 & .230 & .377 & .196 \\
\hline
\end{tabular}

Note: All variables are first differenced. Independent variables measured as z-scores. Estimation by Prais-Winsten regression. Panel corrected standard errors in parentheses. Model 10 excludes Switzerland (CH), United Kingdom (UK), and United States (US).

Model 11 includes LMEs only.

Model 12 includes CMEs only.

$\dagger=\mathrm{p}<.10 ;^{*}=\mathrm{p}<.05 ;^{* *}=\mathrm{p}<.01 ;^{* * *}=\mathrm{p}<.001$. 
Table A1. Regression Estimates of Individual Indicators of Financialization as Determinants of Union Density (Controls Included but Not Reported)

\begin{tabular}{llllll}
\hline \hline & \multicolumn{1}{c}{$(1)$} & $(2)$ & $(3)$ & $(4)$ & \multicolumn{1}{c}{$(5)$} \\
\hline Stock Market Index & & & & & \\
$\quad$ Stock market capitalization & $-.167^{* *}$ & & & & $-.227^{*}$ \\
& $(.027)$ & & & & $(.105)$ \\
Stock market trading activity & & $-.231^{* *}$ & & & $-.229^{*}$ \\
& & $(.076)$ & & & $(.092)$ \\
Portfolio Index & & & & & \\
$\quad$ Inward portfolio investment & & & $-.436^{*}$ & & -.267 \\
& & & $(.202)$ & & $(.199)$ \\
Capital account openness & & & & $-.287^{*}$ & $-.234^{*}$ \\
& & & & $(.117)$ & $(.082)$ \\
& & & & \\
\hline All control variables included? & Yes & Yes & Yes & Yes & Yes \\
Number of countries & 18 & 18 & 18 & 18 & 18 \\
Number of observations & 597 & 561 & 684 & 670 & 527 \\
R-squared & .225 & .211 & .150 & .164 & .241 \\
\hline \hline
\end{tabular}

Note: All variables are first differenced. Independent variables measured as z-scores. Estimation by Prais-Winsten regression. Panel corrected standard errors in parentheses. $\mathrm{t}=\mathrm{p}<.10 ;^{*}=\mathrm{p}<.05$; $^{* *}=\mathrm{p}<.01$; $^{* * *}=\mathrm{p}<.001$. 
Table A2. Error Correction Model: Regression Estimates of Financialization as a Determinant of Union Density (Controls Included but Not Reported)

\begin{tabular}{|c|c|c|c|c|c|}
\hline & $(1)$ & $(2)$ & (3) & (4) & (5) \\
\hline Stock market index $\Delta$ & $\begin{array}{l}-.272^{* *} \\
(.088)\end{array}$ & & & & $\begin{array}{l}-.227^{*} \\
(.105)\end{array}$ \\
\hline Stock market index $\mathrm{t}-1$ & $\begin{array}{l}-.156^{* *} \\
(.051)\end{array}$ & & & & $\begin{array}{l}-.101 \dagger \\
(.049)\end{array}$ \\
\hline Inward portfolio index $\Delta$ & & $\begin{array}{l}-.478^{* *} \\
(.169)\end{array}$ & & & $\begin{array}{l}-.150 \\
(.199)\end{array}$ \\
\hline Inward portfolio index $\mathrm{t}-1$ & & $\begin{array}{l}-.026 \\
(.064)\end{array}$ & & & $\begin{array}{l}-.154 \dagger \\
(.082)\end{array}$ \\
\hline Financial sector size $\Delta$ & & & $\begin{array}{l}-.185 \dagger \\
(.101)\end{array}$ & & $\begin{array}{l}-.140^{*} \\
(.069)\end{array}$ \\
\hline Financial sector size $\mathrm{t}-1$ & & & $\begin{array}{l}-.082 \dagger \\
(.045)\end{array}$ & & $\begin{array}{l}-.011 \\
(.031)\end{array}$ \\
\hline Corporate indebtedness $\Delta$ & & & & $\begin{array}{l}.001 \\
(.005)\end{array}$ & $\begin{array}{l}.001 \\
(.005)\end{array}$ \\
\hline Corporate indebtedness $\mathrm{t}-1$ & & & & $\begin{array}{l}-.003 \\
(.002)\end{array}$ & $\begin{array}{l}-.004 \dagger \\
(.002)\end{array}$ \\
\hline $\begin{array}{l}\text { Fixed effect dummies } \\
\text { included? }\end{array}$ & Yes & Yes & Yes & Yes & Yes \\
\hline All control variables included? & Yes & Yes & Yes & Yes & Yes \\
\hline Number of countries & 18 & 18 & 18 & 18 & 18 \\
\hline Number of observations & 583 & 694 & 684 & 609 & 544 \\
\hline R-squared & .358 & .339 & .336 & .333 & .347 \\
\hline
\end{tabular}

Note: Control variables from the baseline model included but not reported. Estimation by Prais-Winsten regression. Numbers in parentheses are panel corrected standard errors. $\dagger=\mathrm{p}<.10 ;^{*}=\mathrm{p}<.05$; $^{* *}=\mathrm{p}<.01$; $^{* * *}=\mathrm{p}<.001$. 
